\title{
A (in)eficácia do Estado Colombiano na aplicação dos princípios orientadores relativos aos deslocados internos
}

\author{
A Colombian State failure in the application of guiding \\ principles for the internally displaced persons
}

\author{
Fernanda Queiroga Silva* \\ Jeane Silva Freitas** \\ Gustavo Rabay Guerra***
}

\begin{abstract}
Resumo
0 presente artigo pretende analisar a proteção internacional dos direitos humanos, no campo de aplicação dos Princípios Orientadores Relativos Aos Deslocados Internos (PORDI), tendo como base um estudo de caso sobre a sua efetividade em relação aos deslocados internos na Colômbia. O caso da Colômbia é emblemático e essencial ao nosso estudo, pois além de apresentar altas cifras de deslocamento interno, recebeu forte influência dos PORDI para formulação do ordenamento interno voltado à proteção dos deslocados, tornando-se assim um instrumento de investigação com os determinantes fundamentais de nossa investigação. Frente aos pontos levantados, sustenta-se que tanto a difusão dos PORDI como o ordenamento jurídico interno não foram suficientes para materialização das garantias dos deslocados, especialmente pela falta de vontade política que se fortalece a partir do momento em que o Estado não encontra uma força normativa específica que o coaja a agir de maneira a proteger os deslocados, o que acaba se tornando o principal desafio dos PORDI.
\end{abstract}

Palavras-chave: Princípios. Direitos Humanos. Deslocados Internos. Colômbia.

\section{Abstract}

This article analyzes the international protection of human rights within the scope of the Guiding Principles on Internal Displacement (PORDI), based on a case study on their effectiveness in relation to internally displaced persons in Colombia. The case of Colombia is emblematic and essential to our study, as well as presenting high numbers of internal displacement, received strong influence of PORDI for formulation of national law aimed at the protection of the displaced, thus becoming a research instrument with the fundamental determinants of our investigation. Faced with the points raised, it is argued that both the dissemination of PORDI as the domestic laws were not enough to materialization of the guarantees of the IDPs, especially the lack of political will is strengthened from the moment that the state does not find a normative force specific that coerce to act in order to protect the displaced, which turns out to be the main challenge of PORDI.

Keyword: Principles. Human Rights. Internally Displaced Persons. Colombia.

\footnotetext{
* Mestra pelo Programa de Pós-Graduação em Ciências Jurídicas da Universidade Federal da Paraíba (PPGCJ/UFPB).

** Mestra pelo Programa de Pós-Graduação em Relações Internacionais da Univeridade Estadual da Paraíba - UEPB.

** Doutor em Direito, Estado e Constituição pela da Universidade de Brasília (UNB). Professor Adjunto do Centro de Ciências Jurídicas da Universidade Federal da Paraíba (CCJ-UFPB).
} 


\section{Introdução}

O deslocamento interno não é um fenômeno recente no sistema internacional, na verdade, os movimentos populacionais dentro e fora dos Estados sempre estiveram presentes na história das Relações Internacionais como uma constante e com diferentes variantes. No decorrer do tempo, as motivações e atenuantes que nortearam as trajetórias dos grupos humanos foram se caracterizando como partes de um processo que hoje se denomina como migrações. Nesse sentido, a onda de conflitos intraestatais, que emergiu especialmente após o final da Guerra Fria, acentuava o quadro de complexidade e persistência da migração forçada, configurada, em particular, pelo fluxo do deslocamento interno.

Dentro dessa conjuntura, poucos Estados ilustram tão precisamente este panorama como a Colômbia. Com efeito, o conflito armado, que perdura na Colômbia por quase cinco décadas, contribuiu para torná-la o Estado com a maior cifra de deslocados no mundo. Das quase 29 (vinte e nove) milhões de pessoas deslocadas atualmente, cerca de cinco milhões se encontram no Estado colombiano (IDMC, 2013, p. 08).

Muitas vezes confundidos com os refugiados, os deslocados internos são pessoas que foram forçadas a sair de suas casas, seja em razão de conflito armado, violência generalizada, abusos aos direitos humanos ou até mesmo crises ambientais, mas que não atravessam uma fronteira internacional para buscar segurança, nem recebem autoridade internacional específica, pelo contrário, permanecem em seu país de origem sob a proteção de seu próprio governo, ainda que este governo possa ser a causa da fuga (KÄLIN; KÜNZLI, 2009, p. 503).

Nesse ponto, voltamo-nos ao campo de estudo do Direito Internacional com o propósito de averiguar os mecanismos internacionais de proteção e defesa dos direitos humanos às pessoas deslocadas internamente (PDIs). A pesquisa tomará como parâmetro de análise os Princípios Orientadores Relativos aos Deslocados Internos (PORDI), único documento internacional específico que trata desta matéria. Consequentemente, faremos um paralelo com as normas existentes no âmbito interno colombiano para que se perceba o fosso existente na proteção nacional das PDIs pelo governo da Colômbia que, paradoxalmente, é um dos agentes do deslocamento e um defensor dos direitos humanos dos deslocados.

A relevância do PORDI para análise desse estudo consiste no fato de que esse documento é o primeiro mecanismo internacional desenvolvido para os deslocados internos. Os Princípios Orientadores - aprovados por consenso na Comissão de Direitos Humanos das Nações Unidas (1998) e endossados por vários Estados e agências internacionais, especialmente no âmbito da ONU e ONGs - buscam tratar as áreas cinzentas e as lacunas presentes na proteção das PDIs. Em razão disso, o presente artigo pretende analisar a proteção internacional dos direitos humanos, no campo da aplicação dos PORDI, tendo como base um estudo de caso sobre a sua efetividade em relação aos deslocados internos na Colômbia.

\section{A Comunidade Internacional frente ao problema do deslocamento interno}

O termo "deslocados internos" apareceu recentemente e derivou de um acordo de paz realizado para cessar um conflito no Sudão nos anos de 1970. Nele, fazia-se referência ao 
grupo de populações deslocadas dentro do contexto particular de uma ação emergencial que promovesse o reassentamento e reabilitação dessas pessoas e, portanto, não tinha uma conotação que fornecesse um precedente para reivindicação de garantias normativas (PHUONG, 2005, p. 14).

$\mathrm{Na}$ verdade, as primeiras iniciativas multilaterais para esta temática surgiram, apenas no final dos anos de 1980, a partir de duas conferências: a Conferência Internacional sobre o problema dos refugiados, repatriados e pessoas deslocadas no Sul da África (1988), e Conferência Internacional sobre Refugiados Centro-Americanos (CIREFCA - 1989) (OLIVEIRA, E. C., 2004, p. 76). Realizadas sob o crivo da Organização das Nações Unidas (ONU), estas duas arenas de discussão divulgaram a problemática das PDIs como um fenômeno generalizado, mas não trouxeram grandes avanços, pois o principal assunto debatido nesta época ainda era a temática dos refugiados.

A comunidade internacional, que tardou a oferecer respostas para esta temática, estava, pois, preocupada em obter soluções para a também complexa questão dos refugiados. Por isso, o pós-1945 testemunhara a construção de mecanismos jurídico-institucionais voltados para proteção destas pessoas. Como resultado, a ONU aprovou em 1951, em Genebra, a Convenção Relativa ao Estatuto dos Refugiados e a criação do Alto Comissário das Nações Unidas para os Refugiados (CUNHA, 2002, p. 503).

Dentro desse contexto, o fenômeno do deslocamento interno permanecia sem respostas e carente de melhores elucidações, devido à analogia que se fazia em relação aos refugiados. As semelhanças e diferenças com esta categoria migratória', assim como os fatores intervenientes durante o processo de deslocamento, dificultaram a separação destes campos, ocasionando até mesmo uma confusão conceitual entre os dois termos.

A comum confusão entre eles existe por serem, na maioria das vezes, as mesmas razões que justificam tanto os deslocamentos internos como os refúgios, afora o fato de não haver uma normativa internacional específica voltada à proteção das PDIs, que acabam recorrendo ao aparato dos direitos internacionais dos direitos humanos e humanitários para obter algum tipo de amparo.

Importante destacar que as abordagens em torno da conceitualização do termo "deslocamento interno" ou "Pessoas Deslocadas Internamente"2 seguem um padrão descritivo e não jurídico, simplesmente porque "describe la situación de hecho de una persona desarraigada en su propio país de residencia. No confiere un estatuto jurídico ni derechos específicos como sí ocurre en el caso de los refugiados" (ONU, 2010, p. 08-09)3.

Ao contrário dos refugiados, o deslocamento interno tende a ser menos visível e, por conseguinte, a conscientização e solidariedade internacional acontecem em menor grau,

1 De acordo com o ACNUR (ONU, 2013b), os deslocados internos representam "grupos numerosos de pessoas que foram forçadas, de forma súbita ou inesperada, a desenraizar-se e a abandonar suas casas, fixando-se em locais diferentes no seu país, devido a conflitos armados, lutas internas, violações sistemáticas dos direitos humanos ou calamidades provocadas pelo homem", de forma análoga, refugiado é "alguém que, temendo ser perseguido por motivos de raça, religião, nacionalidade, grupo social ou opiniões políticas, se encontra fora do país de sua nacionalidade e que não pode ou, em virtude desse temor, não quer valer-se da proteção desse país" (ONU, 1951, art. 10, "c").

2 Por serem os termos similares, eles serão usados indistintamente ao longo do trabalho.

3 Trad.: "descreve de fato a situação de uma pessoa desenraizada em seu próprio país de residência. Não confere um estatuto jurídico nem deveres específicos, como acontece no caso dos refugiados." (tradução livre). 
o que significa dizer que suas vítimas dependem prioritariamente da capacidade de resposta do Estado. Contudo, apresenta-se como um problema de longa duração para as localidades onde ocorre, ocasionando desequilíbrios social, econômico e, muitas vezes, político (OLIVEIRA, E. C., 2004, p. 75).

Atentando para este fato, a sociedade de Estados, em meados da década de 1990, passou a discutir com preocupação o tema, pois o referido não poderia continuar à margem das discussões internacionais, devido às possíveis ameaças que sua extensão poderia provocar para a manutenção da ordem e paz mundiais.

Neste campo, a Comissão de Direitos Humanos da ONU - motivada pelo primeiro relatório analítico sobre os deslocados internos, submetido pelo então secretário-geral Boutros BoutrosChali (1992-1996) - abriu caminho para um exame específico sobre o deslocamento interno quando aprovou a resolução 1992/73, com o intuito de estabelecer um representante especial que se dedicasse ao estudo do tema e pudesse obter informações de todos os governos com relação aos deslocados internos, incluindo a investigação das normas - direito humanitário, direito internacional dos direitos humanos e direito internacional dos refugiados - que poderiam ser aplicadas na assistência às PDls. Com esse objetivo, o diplomata sudanês Dr. Francis Deng foi nomeado para o cargo de Representante Especial do Secretário-Ceral para Deslocados Internos e assumiu a responsabilidade de produzir novos relatórios (WEISS; KORN, 2006, p. 02).

Em consequência do relatório apresentado por Deng, a resposta internacional ao problema da deslocação se reestruturou segundo o enfoque colaborativo, o que significa dizer que as agências especializadas da ONU e outras instituições internacionais assumiam a responsabilidade conjunta de promover assistência aos deslocados. O Secretário-Geral, pesando argumentos de viabilidade política, endossou essa abordagem e reafirmou a responsabilidade do ERC em garantir proteção e assistência às PDIs, pois não existia, à época, vontade política, nem recursos financeiros para que fosse criada uma nova agência. A possibilidade de extensão do mandato do ACNUR, para que assumisse completa responsabilidade sobre os PDIs, também foi rejeitada sob o argumento de que iria sobrecarregá-la, pelo fato do problema apresentar extrema gravidade e grande proporção para serem atendidas por uma única agência (OLIVEIRA, E. C., 2004, p. 77).

Nesse interstício, um grupo de estudiosos, ligados aos organismos da ONU e imbuídos pelas ideias expostas no relatório apresentado por Deng, iniciaram um processo de pesquisa, que reconheceria, a partir dos instrumentos normativos já existentes - Direito Internacional Humanitário (DIH), Direito Internacional dos Direitos Humanos (DIDH) e o Direito Internacional dos Refugiados -, aqueles que poderiam ser aplicados para o atendimento e proteção das PDIs (DARIO, 2009, p. 111).

Desta pesquisa resultou a redação dos chamados Princípios-Guia sobre o Deslocamento Interno (ONU, 1998), no qual convergiam os três escopos do direito internacional supracitados. Os Princípios Orientadores Relativos aos deslocados internos foram submetidos para aprovação da Comissão de Direitos Humanos em 1998, pelo então Secretário Geral da ONU sobre a questão dos Deslocados Internos, Francis Deng.

Desde então, os Princípios Orientadores têm servido como "norma internacional para orientar os governos, as organizações internacionais/regionais e todos os atores pertinentes na 
provisão de assistência e proteção aos deslocados internos" e, mesmo sem possuir o caráter de corpo normativo vinculante, os princípios refletem e são consequentes do Direito Internacional e, portanto, identificam os direitos e garantias relacionadas com a proteção das PDIs, em razão das vulnerabilidades específicas por elas enfrentadas (GLOBAL DATABASE, 2013).

\section{Princípios Orientadores Relativos aos Deslocados Internos (PORDI)}

Conforme mencionado anteriormente, os Princípios Orientadores relativos aos Deslocados Internos resultaram de uma abordagem conjunta entre o Direito Internacional dos Direitos Humanos, o Direito Internacional Humanitário e, por analogia, o Direito Internacional dos Refugiados. Embora nenhum destes ramos tenha apresentado uma proteção completa aos deslocados internos, uma perspectiva convergente, como foi adotada neste caso, representa um amparo mais abrangente, o que consequentemente aumenta as chances de salvaguarda das necessidades das PDIs.

Cançado Trindade (2001, p. 63) assinala que uma recente corrente doutrinária admite a interação normativa entre estes três ramos jurídicos, afirmando que mesmo a ênfase exagerada às suas distintas origens não impediu que pudessem se manifestar as convergências entre estas vertentes. De toda forma, ele ressalta que a interação entre eles não ocorre de forma inequívoca, uma vez que não é possível observar uma uniformidade total nos planos tanto substantivo como processual.

Dessa forma, a consubstanciação destes três ramos jurídicos internacionais nos PORDI torna-se, sem dúvida, legítima e passivel de obter melhores elucidações acerca das necessidades e direitos referentes às PDIs.

Neste contexto, um preceito fundamental subjacente aos Princípios Orientadores é a ideia da articulação "soberania como responsabilidade". Recentemente levantado por Roberta Cohen, que trabalhou com os deslocados internos no Refugee Policy Group em Washington (1991), e mais tarde endossado por Francis Deng, primeiro Representante do Secretário-Geral da ONU sobre a questão dos deslocados internos, o termo soberania foi empregado como uma fórmula para responsabilizar os Estados pela proteção de seus cidadãos. Em outras palavras, a soberania efetiva implica um sistema de direito que dê resposta às necessidades da população. Nesse caso, quando o Estado não for capaz de assegurar ou obstruir o acesso aos direitos fundamentais da população, possui o direito de solicitar o auxílio externo, o que significa dizer que a comunidade internacional também pode conceder assistência humanitária de tal modo que promova a proteção dos deslocados internos, agindo de maneira a preencher essa lacuna (EVANS, 2008, p. 36).

Assim, os PORDI (ONU, 1998) expressam que, coerente com sua obrigação de respeitar o direito internacional, incluindo os direitos humanos e humanitário, os Estados e demais atores internacionais devem "prevenir e evitar as situações que possam levar ao deslocamento" (ONU, 1998, princípio 5) e, caso ocorra, os deslocados internos devem ter assegurado "o direito de receber ou solicitar proteção e assistência humanitária do governo, e de não poder sofrer qualquer tipo de perseguição ou punição por fazerem tal pedido" (ONU, 1998, princípio 3). 
De acordo com Martin (1999, p. 08-11), além do princípio da soberania como responsabilidade, a proteção prevista pelos PORDI têm por base outros três fundamentos gerais (ONU, 1998, princípios 1-4), apresentados na primeira seção do documento, quais sejam: a igualdade de direitos e obrigações, que implica no direito de não discriminar os deslocados internos em razão da sua condição, pois eles são detentores dos mesmos direitos e deveres aplicados aos outros indivíduos do seu Estado; o escopo de aplicação universal, por funcionarem como normas do direito internacional consuetudinário e, em especial, por servirem de padrão internacional para orientar os governos e demais agências e organizações humanitárias; por fim, o direito de procurar e se beneficiar de asilo, pois salientam que as PDIs podem se asilar em outros Estados.

Desta forma, os PORDI lidam com todas as fases do deslocamento, ou seja, abordam desde a prevenção do desenraizamento ilegal, a proteção durante o deslocamento até o seu regresso ou reinstalação e reintegração ao local de origem. Composto por 30 princípios, eles foram apresentados em cinco seções diferentes, a saber: princípios gerais, princípios referentes à proteção contra a deslocação, princípios referentes à proteção durante a deslocação, princípios referentes à assistência humanitária e princípios referentes ao regresso, reinstalação e reintegração.

Neste ponto, cabe destacar que, na introdução aos princípios, os deslocados internos são descritos, mas não titularmente definidos, como:

pessoas, ou grupos de pessoas, forçadas ou obrigadas a fugir ou abandonar as suas casas ou seus locais de residência habituais, particularmente em consequência de, ou com vista a evitar, os efeitos dos conflitos armados, situações de violência generalizada, violações dos direitos humanos ou calamidades humanas ou naturais, e que não tenham atravessado uma fronteira internacionalmente reconhecida de um Estado. (ONU, 1998)

Portanto, os PORDI não se aplicam aos migrantes que voluntariamente deixam suas residências por motivações econômicas, sociais e culturais.

Para Nascimento (2011), esta descrição ainda pode ser considerada insuficiente, pois deixa de fora as razões econômicas, abrindo uma lacuna com relação à proteção dos deslocados que porventura são forçados a se deslocarem em consequência de projetos de desenvolvimento em grande escala. Aliás, a diversidade de fatores causadores do desenraizamento pode gerar até mesmo uma confusão na determinação formal das PDIs e problematizar as políticas de proteção (NASCIMENTO, 2011, p. 121).

Em seguida, a seção II (ONU, 1998, princípios de 5 a 9) fornece os princípios preventivos ao deslocamento involuntário, abordando explicitamente os motivos e as condições em que a deslocação é inadmissivel e as garantias mínimas que devem ser cumpridas se o desenraizamento ocorrer. Os PORDI evidenciam, por exemplo, que a deslocação arbitrária é proibida quando provocada por políticas de apartheid, limpeza étnica ou outras práticas similares, com vista a promover uma alteração étnica, religiosa ou racial (ONU, 1998, princípio 6). Eles consideram também, apesar de não incluir na descrição das PDIs, a vedação ao deslocamento em casos de projetos de desenvolvimento em larga escala, em que não se justifique a exclusão e destruição dos interesses públicos (ONU, 1998, princípio 6). 
De igual modo, a deslocação não deve ser realizada quando ameaçarem os direitos à vida, dignidade, liberdade e segurança dos indivíduos (ONU, 1998, princípio 8). Há uma advertência em particular com relação à obrigação dos Estados em garantir a proteção de grupos de pessoas - como indígenas e camponeses - que tenham dependência e/ou ligação especial com suas terras (ONU, 1998, princípio 9). E, mesmo se com todas as prevenções, o deslocamento for necessário como garantia da segurança das pessoas de uma determinada região, os Estados devem assegurar que seja fornecido alojamento adequado aos deslocados, assim como fornecer os meios essenciais à sua sobrevivência e cuidar para que não haja desagregação familiar (ONU, 1998, princípio 7) (COHEN, 1998, p. 32).

A seção relativa à proteção durante o deslocamento (princípios 10 ao 23) abrange uma ampla gama de direitos, essencialmente de caráter declaratório de direito consuetudinário. A maioria das ressalvas reafirma as normas específicas dos direitos humanos e humanitário, com alguma analogia ao direito dos refugiados. Dentre os princípios elencados, merece destaque o preceito que proíbe toda e qualquer forma de violência individual ou coletiva (ONU, 1998, princípio 11), que impede, em todas as circunstâncias, o recrutamento ou permite que as crianças deslocadas tomem parte nas hostilidades (ONU, 1998, princípio 13), além da garantia de poder procurar asilo em outro Estado, de serem protegidos contra o regresso forçado a qualquer lugar que coloque em risco sua vida, segurança, liberdade e/ou saúde (ONU, 1998, princípio 15).

Na seção IV dos PORDI é apresentada, sem elucidações precisas e detalhadas, a questão da assistência humanitária (ONU, 1998, princípios do 24-27). Pela sua especial importância, os princípios relativos à prestação de assistência aos deslocados internos mereciam uma melhor apreciação no referido documento. Em resumo, as contribuições deste ponto remetem tanto ao dever do Estado em prestar assistência aos deslocados, como ao direito das organizações humanitárias internacionais e outros atores apropriados de oferecerem os seus serviços de apoio às PDIs, de tal modo que sejam observadas as necessidades mais urgentes apresentadas por elas (ONU, 1998, princípio 25). Para tanto, os governos e os grupos participantes das hostilidades devem respeitar e proteger os transportes e provisões dos representantes da ajuda humanitária (ONU, 1998, princípio 26).

A última seção (ONU, 1998, princípios 28 ao 30) traz os princípios relativos aos reassentamento e reintegração das PDIs ao local de origem. Dois pontos mencionados neste tópico merecem destaque: primeiro, o fato de garantir o direito de retorno, assegurando a participação plena dos deslocados internos no planejamento e gestão do seu regresso, isto porque muitas vezes os deslocados são forçados a residirem em partes do país inseguras (princípio 28); e, segundo, a recuperação da propriedade e bens perdidos como resultado do deslocamento, e mesmo se não for possivel, as autoridades competentes deverão fornecer uma compensação ou reparação dos danos de forma justa (ONU, 1998, princípio 29).

Conforme aponta Williams (2008, p. 23), não existia provisão anterior que garantisse às PDIs o direito de recuperarem a propriedade abandonada, nem solucionassem a questão da compensação e restituição, mesmo assim, os autores dos PORDI elucidaram este princípio como um dos elementos indispensáveis para reintegração dos deslocados na sociedade e para plena salvaguarda dos seus direitos. De todo modo, a contribuição dos PORDI não foi suficiente para o 
desenvolvimento deste direito, pois seguem ocorrendo inúmeros obstáculos para sua aplicação sistemática nos desenraizamentos.

$\mathrm{Na}$ verdade, poucos são os casos em que ocorreu a materialização desta garantia, Williams (2008, p. 23) cita o Acordo de Paz de Dayton4, em 1995, como um precedente para restituição da propriedade aos deslocados internos. Num período de cinco anos foi promovida uma política de restituição da propriedade que levou ao retorno de quase um milhão de pessoas às suas residências. Afora esse exemplo, o que temos presenciado é uma contínua falha na sua implementação, derivada, em parte, dos desvios políticos de governos que veem algumas terras ou moradias como bens valiosos e com isso dificultam a sua recuperação. De outro lado, nos casos em que há vontade política, os programas de restituição requerem recursos e capacidades que alguns países não detêm. Outro desafio significativo é a restauração de terras aos grupos indígenas ou tribais, tendo em vista que em muitos países eles não possuem o reconhecimento formal da propriedade, ou seja, é preciso incorporar aos PORDI uma proteção diferenciada entre o campo e zonas urbanas.

Feita essa leitura acerca dos PORDI, constatamos que as provisões criadas para salvaguardar os direitos dos deslocados internos não pretendem garantir uma condição de privilégios, mas, sobretudo, determinar a proteção das PDIs como qualquer outro grupo que seja alvo de violações. Para Cohen e Deng (2008, p. 06), apesar dos esforços para elaboração deste conteúdo, surgiram ainda diversas controvérsias, mas não tanto pela sua matéria e sim pela sua forma de desenvolvimento e desrespeito da lei, uma vez que ainda perduram grandes desafios que impedem o cumprimento dos direitos dos deslocados internos.

\section{As variadas dimensões do conflito colombiano}

A história da Colômbia praticamente se confunde com as experiências do conflito interno. Para a população deste Estado, a violência sempre esteve tão presente e enraizada que muitos não se imaginam vivendo em um Estado tranquilo, pacífico. Seria difícil encontrar alguém ou alguma família que não tenha sido, direta ou indiretamente, afetado pelo conflito. Nesse contexto, a experiência peculiar deste povo tem construído uma memória com as marcas de uma realidade com confrontos recorrentes entre as diferentes organizações políticas e sociais.

Originado como um combate entre guerrilhas, após um período de violentas disputas partidárias, no cenário ideológico da Guerra Fria, o conflito armado que a Colômbia vivencia, por mais de cinco décadas, é considerado um dos mais antigos do mundo. Ao longo do tempo, o conflito colombiano foi intensificando-se e adquirindo uma dimensão crônica, modificando parte de suas motivações, diversificando seus atores e formas de atuação, com consequências desastrosas para sociedade civil, que foi se tornando o principal alvo dos embates (SANTOS, M., 2011, p. 13).

Isso porque existem diversas causas para o deslocamento na Colômbia. Para Viana (2009, p. 139), a violência propagada pelo conflito armado tem ocasionado um processo paralelo de

4 Determinou o encerramento da Guerra na Bósnia, entre sérvios, croatas e mulçumanos, conhecida como o pior conflito armado da Europa após a Il Guerra Mundial. 
desenraizamento interno. Com efeito, o desencadeamento dos deslocamentos já podia ser observado ainda no período de independência do Estado, quando as disputas pelo poder entre os dois tradicionais partidos colombianos - o conservador e o liberal - e as lutas pela posse das terras se intensificaram e geraram uma onda de violência que caracteriza e perdura nos acontecimentos políticos do Estado desde então.

Longe de ser a única razão para o deslocamento interno na Colômbia, a violência pode ser tomada como fator preponderante no estudo deste fenômeno. De todo modo, além da violência e da questão agrária, há ainda outros fatores condicionantes para o deslocamento interno neste Estado, como a ineficácia do sistema judicial, a ausência de mecanismos eficientes para solução pacífica de controvérsias entre os cidadãos, acompanhada da violação maciça dos Direitos Humanos e desrespeito às regras do Direito Humanitário Internacional, disputa por territórios geoestratégicos e motivações sociais (FRANCO, 1998, p. 07-08).

Assim, fica claro que o deslocamento forçado na Colômbia não é apenas um subproduto de confrontos armados entre grupos, na verdade, é raro o combate direto entre as partes envolvidas no conflito (NRC, 2002, p. 88). Este fenômeno é o reflexo de um conjunto de ações violentas perpetradas contra os civis como forma de intimidar o "outro lado" do conflito, apontada pelo Conselho Norueguês para Refugiados (NRC, sigla em inglês, 2002, p. 88) como "estratégia deliberada de guerra exercida para estabelecer domínio em determinadas terras, em sua maioria, para expandir o cultivo de produtos ilícitos".

Além disso, há que se levar em consideração que o caso da Colômbia se apresenta dentro de um conjunto de variáveis endógenas, que abarcam desde os aspectos geográficos até ideológicos, e que da mesma forma adquirem efeito spillover ${ }^{5}$ não apenas para o Estado, mas também em nível regional e internacional, a partir do momento em que variáveis exógenas passaram a influenciar na conduta do governo colombiano.

Para Kurtenbach (2005, p. 14), esta cultura política da violência está tão enraizada no cotidiano da Colômbia, que foi se instrumentalizando em vários seguimentos da sociedade. Fato esse registrado desde a independência do país, quando a oligarquia procurava conseguir a integração clientelista da população, até hoje, na maneira como os grupos armados usam a violência para influenciar nos processos eleitorais e na obtenção de recursos econômicos. Importante destacar que o conflito registrado na Colômbia está também diretamente relacionado com o acesso desigual à terra e a outros recursos naturais ${ }^{6}$. Há a questão do narcotráfico, mas também a necessidade de uma reforma agrária no Estado, além das disputas pela exploração de recursos naturais, como o petróleo e esmeraldas (KURTENBACH, 2005, p. 16).

A complexidade e a durabilidade do conflito na Colômbia dificultam uma simplificação dos atores envolvidos, especialmente porque houve uma diversificação dos seus atores ao longo de seu desdobramento. Por isso, nesta parte do texto, destacamos resumidamente as peças-chave mais atuantes do conflito, ou seja, as guerrilhas e os paramilitares, a fim de promover uma

5 Efeito de transbordamento: são os efeitos de políticas ou medidas adotadas em um Estado ou grupos de Estados numa determinada área de conhecimento e que se estendem para outros setores ou lugares.

6 A economia colombiana está baseada principalmente na agricultura e pecuária. É o maior produtor mundial de esmeraldas e possui as maiores reservas de carvão mineral da América Latina. Entre os principais produtos exportados pelo Estado estão: petróleo, carvão, café, cana-de-açúcar, têxteis e couro (CONSULADO HONORÁRIO DA COLÔMBIA, 2005, s/p). 
melhor compreensão do atual conflito colombiano. Visualizando a figura 1, abaixo, poderemos entender melhor essa divisão:

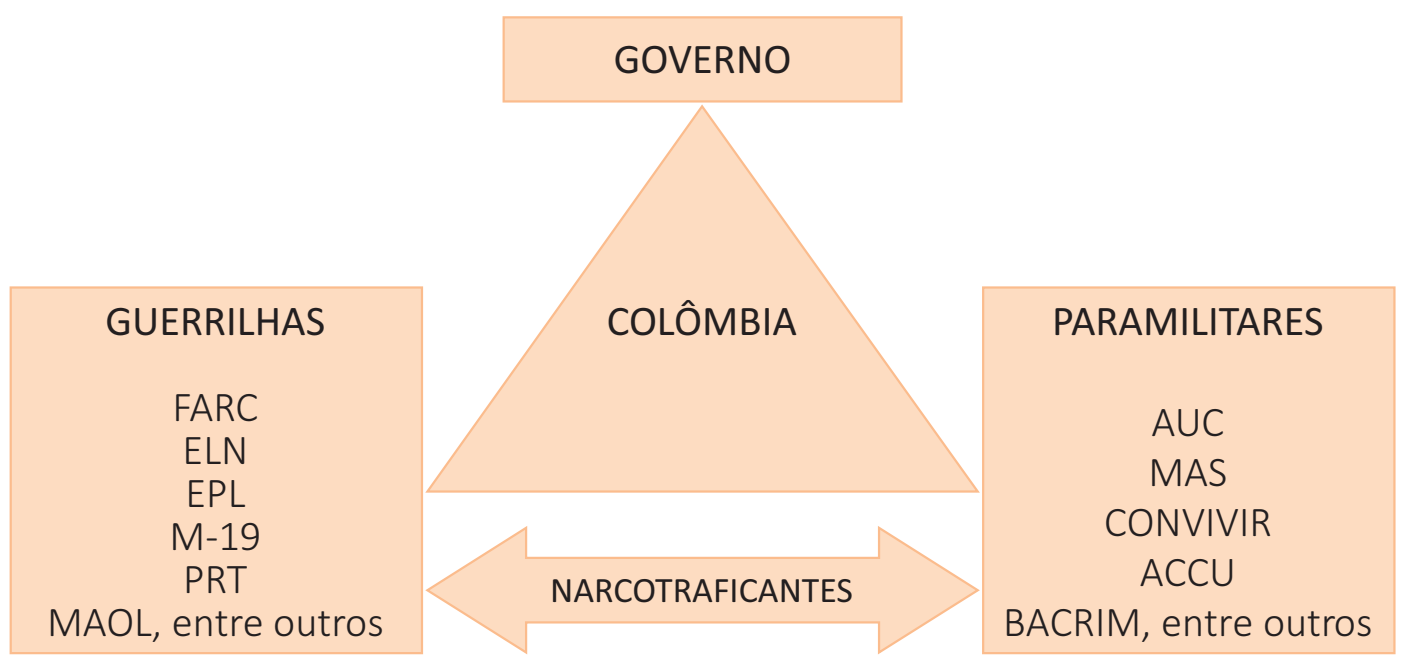

Figura 1 - Peças-chave no conflito colombiano

Fonte: adaptado com base nas informações constantes no sítio eletrônico da Corporatión Nuevo Arco Iris (2012).

No rol dos grupos assinalados na figura 1, destacamos dentre as guerrilhas, as Fuerzas Armadas Revolucionarias de Colombia (FARC) e Ejército de Liberación Nacional (ELN); e, no que se refere aos paramilitares, a Autodefesas Armadas da Colômbia (AUC) e as Bandas Criminales Emergentes (BACRIM), em virtude da atuação proeminente no território colombiano até o momento. Nos mais de 50 anos, o conflito colombiano experimentou diferentes momentos, a partir de quadros conjunturais com causas e atores variados. Embora o Estado tenha assumido, em boa parte dos seus governos, uma política de combate ao conflito armado, suas posições foram heterogêneas e provocativas, atenuando em muitos casos os fatores que levavam à violência (SANTOS, M., 2011, p. 38). Além da incapacidade de enfrentar militarmente os grupos ilegais, o Estado adotava políticas que favoreciam as elites e enfraqueciam sua relação com as camadas mais pobres da população - incrementadas pelas deficiências em relação à questão agrária, grande motivo das discórdias - além da sua posição ideológica favorável aos interesses norte-americanos.

\section{Características do Deslocamento Interno na Colômbia}

Por ora, os apontamentos abordados corroboram a visão de que as disputas, ameaças e violência decorrentes do conflito armado colombiano são os grandes propulsores do deslocamento interno. Contudo, não podemos negligenciar que fatores como a disputa por territórios, terras e motivações sociais e econômicas também fazem parte das causas que levaram tanto à intensificação do conflito como ao aumento do desenraizamento da população (VIANA, 2009, p. 140). 
Ademais, evidencia-se no caso colombiano uma ligação direta entre os fatores do deslocamento e os diversos atores do conflito interno. Além das ações proferidas pelos grupos armados, Viana (2009, p. 141) aponta a própria responsabilidade do Estado na trajetória do conflito armado - seja pela omissão em garantir a segurança física e institucional da população, assim como pelas tentativas frustradas de conter as hostilidades, por meio do uso, muitas vezes, indiscriminado da força - e a participação de grupos econômicos e dos narcotraficantes, que procuram garantir a manutenção e exploração da terra por meios ilegais, condicionaram a dinâmica do deslocamento.

De outro lado, Murcia (2002, p. 52) também afirma que os desenraizamentos nem sempre respondem a ações armadas específicas, às vezes o simples fato da chegada das guerrilhas ou dos paramilitares em determinada região se converte em uma justificativa para a saída da população, uma vez que esses grupos utilizam a ameaça para coagir os civis a deixarem suas casas.

Ainda na visão de Murcia (2002, p. 53), existem, de igual modo, alguns determinantes estruturais sobre o deslocamento forçado colombiano, como a pobreza - abarcando a falta de oportunidades e o subdesenvolvimento; o vazio estatal - entendido como a ausência de forças militares e juizados, assim como de serviços sociais e de formas democráticas de participação; o modelo de desenvolvimento econômico excludente e inequitativo - promovido pela concentração de renda, sistema de discriminação e marginalidade do campesinato e da economia rural; e, por fim, as zonas de maior dinamismo econômico, nas quais há abundância de recursos estratégicos, matérias-primas e terras favoráveis ao cultivo de ilícitos.

Mesmo com essa caracterização abrangente do deslocamento interno na Colômbia, pesa sobre este fenômeno a ênfase de que a conjugação entre os interesses econômicos e políticos sobre as terras e territórios e os confrontos entre os atores armados são suas causas principais. De acordo com o Grupo de Memoria Histórica (GMH) (CENTRO NACIONAL DE MEMORIA HISTÓRICA, 2013, p. 71) da Colômbia, as ações do narcotráfico e suas estruturas de financiamento, assim como os interesses provenientes dos setores empresariais têm propiciado o despojo e a apropriação de territórios com recursos estratégicos.

O GMH (CENTRO NACIONAL DE MEMORIA HISTÓRICA, 2013, p. 71) afirma que o agravamento da expulsão da população civil responde, em primeiro lugar, à expansão dos domínios por grupos guerrilheiros e agora também dos BACRIM; às deficiências em seus processos de desmobilização; à ofensiva militar do Estado em cumprimento da Política de Segurança Democrática; e a um conjunto de ações violentas disseminadas desde 1996, quando houve um recrudescimento do conflito, até 2002, sucedidas por uma instabilidade interna que perdura até hoje.

Essas manifestações do conflito armado e da violência generalizada contra a população civil estão entre os principais fatores do deslocamento, identificados, na tabela 1, pela Coordinación de Atención al Desplazamiento Forzado (2011, p. 08), como: 
Tabela 1 - Manifestações do conflito armado interno e da violência generalizada

\begin{tabular}{|c|c|c|}
\hline $\begin{array}{l}\text { Ameaças de morte: direcionada } \\
\text { para membros da comunidade, } \\
\text { especialmente contra os líderes e } \\
\text { representantes da população civil. }\end{array}$ & $\begin{array}{l}\text { Ataques indiscriminados contra } \\
\text { unidades e instalações policiais ou } \\
\text { militares. } \\
\text { Ataques indiscriminados a bens civis. }\end{array}$ & $\begin{array}{l}\text { Acidentes por minas } \\
\text { antipessoais e artefatos } \\
\text { explosivos não convencionais. }\end{array}$ \\
\hline $\begin{array}{l}\text { Instalações das forças de segurança e } \\
\text { policiais no meio da população civil, que } \\
\text { coloca os civis em meio aos ataques. }\end{array}$ & $\begin{array}{l}\text { Expansão das cadeias ilegais do } \\
\text { narcotráfico, que tem efeito direto } \\
\text { para a população civil, como as } \\
\text { fumigações de cultivos ilícitos. }\end{array}$ & $\begin{array}{l}\text { Restrições à mobilidade } \\
\text { da população civil e bens } \\
\text { indispensáveis à subsistência. }\end{array}$ \\
\hline Sequestros & Massacres & Execuções \\
\hline Extorsões & $\begin{array}{l}\text { Tortura e maus tratos: prática do } \\
\text { confinamento. }\end{array}$ & Desaparição forçada \\
\hline Atentados à vida e integridade pessoal & Recrutamento forçado & Violência sexual \\
\hline Furto de bens da população civil. & $\begin{array}{l}\text { Ameaças ou ataques a entidades } \\
\text { governamentais. }\end{array}$ & $\begin{array}{l}\text { Ataque ou ocupação de bens } \\
\text { civis e comunitários. }\end{array}$ \\
\hline
\end{tabular}

Fonte: Tabela elaborada pela autora do trabalho com base nas informações constantes no informe 2011 da Coordinación de Atención al Desplazamiento Forzado, Defensoría del Pueblo (COLÔMBIA, 2011).

Dentre as ações empregadas contra a população, o Internal Displacement Monitoring Centre (IDMC, 2011b, p. 20) destaca que as ameaças diretas, os massacres, assassinatos, combates, assassinatos, ameaças indiretas e o recrutamento forçado são os fatores proeminentes para o deslocamento interno colombiano.

\section{Panorama da situação dos Deslocados Internos na Colômbia}

O deslocamento interno na Colômbia adquiriu uma proporção tão preocupante ao longo dos anos, que se refletiu de maneira dispersa e irregular, e demonstrou a baixa capacidade do Estado em responder a este cenário de crise humanitária. Essa conjuntura contribuiu para que a população deslocada acabasse imersa em uma situação de permanente desamparo e vulnerabilidade.

Segundo Springer (2006, p. 16), os efeitos do deslocamento interno podem ser sentidos tanto em curto e médio prazo como em longo prazo, especialmente nos casos de pessoas que estão continuamente se deslocando. Em termos de curto e médio prazo, as PDIs podem sofrer com a perda de autoestima, depressão, desejo de vingança, enfermidades, ansiedade e desespero, ou seja, provoca danos mais psicológicos, em razão do sentimento de impotência diante da fuga. Em se tratando dos efeitos em longo prazo, os indivíduos deslocados passam a enfrentar graves problemas socioeconômicos, como a deterioração das condições de vida, perda da identidade local ou regional, aumento das barreiras sociais, desintegração familiar, desemprego, marginalização política, perda de credibilidade das instituições públicas, destruição de projetos de vida particulares e ruptura das redes socais e afetivas. 
De fato, esses efeitos podem ser diagnosticados no contexto conflituoso da Colômbia, que por sua própria experiência de intensa violência criou um profundo trauma para as PDIs e tornou-se ainda mais complexa pela sua estigmatização e marginalização frente ao restante da sociedade, tendo em vista que o governo colombiano vem adotando um discurso falacioso acerca do impacto do conflito armado, a fim de neutralizar suas consequências sobre a população. Contudo, esta aparente negação acaba dificultando a visibilidade dos deslocados internos, que são a expressão mais evidente da violência excessiva que impera nas várias regiões do Estado, em especial nas zonas rurais e periféricas. Esta atitude patológica faz com que muitos deslocados internos evitem ser identificados dentro dessa categoria, com o propósito de ocultar sua condição de migração forçada, e assim não sofrerem discriminação social e estigmatização (SPRINGER, 2006, p. 17).

Uma prova disso é que há grandes divergências nos índices do deslocamento interno colombiano divulgados entre as instituições nacionais e os organismos internacionais. A Coordinación de Atención al Desplazamiento Forzado (2011, p. 14-15) chama atenção para esse fato, ao assinalar que enquanto o Observatorio Nacional de Desplazamiento informava que havia ocorrido uma diminuição do deslocamento interno na Colômbia, em 2011, no mesmo período o IDMC tinha verificado o incremento tanto dos deslocamentos massivos como dos individuais. Ainda nesse ano, o Observatorio Nacional de Desplazamiento Forzado (2011, s/p) apontou que das quase 132 mil famílias afetadas pelo deslocamento interno, 27\% não se incluíram como deslocados.

Em razão disso, segue que a problemática deste fenômeno na Colômbia não corresponde exclusivamente ao fato das pessoas se deslocarem forçadamente, mas as consequências advindas dessa expulsão abarcam uma série de violações aos direitos humanos e aos princípios humanitários, que evidenciam a inadequada resposta governamental à situação das PDIs. Mesmo que o desenraizamento seja causado por inúmeros agentes do conflito armado, o Estado colombiano é diretamente responsável por esta crise, porque viola seus compromissos constitucionais e internacionais para a proteção dos Direitos Humanos das PDIs.

De acordo com o recente informe do IDMC (2011b, p. 35), a situação socioeconômica dos deslocados internos é considerada muito pior do que a população em nível de pobreza na Colômbia. Para o IDMC (2011b, p. 35), o comparativo entre os indicadores nacionais comprova tal assertiva, tendo em vista que, entre 2008 e 2010, os dados revelaram que $97,6 \%$ (2010) das famílias deslocadas estavam abaixo da linha da pobreza e 78,8\% (2010) possuíam renda inferior à linha de indigência. Estes níveis são muito superiores ao percentual total da população de baixa renda, no qual 45\% estão abaixo da linha de pobreza, enquanto 17\% têm renda inferior à linha de indigência.

Outras investigações também têm demonstrado as graves repercussões do deslocamento interno sobre as condições de vida das PDIs, como o estudo realizado por Bello e Bonilla (2010) para análise das capacidades materiais dos deslocados frente à população não deslocada, no período de 2003 a 2009. Nesta pesquisa, verificou-se que as habitações das PDIs são piores que a dos receptores, ou seja, deterioraram-se com o deslocamento. Antes do desenraizamento, 95\% dos deslocados viviam em casa ou apartamento, e agora apenas 7\% conservam esta condição. Boa parte dos deslocados (48\%) reside em habitações compartilhadas por várias famílias, 
o denominado "cuarto de inquilinato" frente a 35\% dos receptores. Quase metade das PDIs constroem suas habitações com papelão, madeira e materiais de sucataria, normalmente com apenas um cômodo.

O direito à habitação é privado no processo de desenraizamento, uma vez que com a expulsão os deslocados acabam deixando para trás a maior parte dos seus bens, especialmente suas casas, saindo praticamente de "mãos vazias" em busca do desconhecido, e com isso acabam se alojando em zonas de invasão, sem infraestrutura, com dificuldade de acesso e que oferecem alto risco à sua sobrevivência.

Nesse contexto, pesa sobre os deslocados a preponderância de problemas, como danos à saúde mental, a desnutrição, a gestação precoce, doenças respiratórias e de pele, justificados dentre outros motivos pelo transtorno do estresse pós-traumático, a ansiedade e a depressão suscitados pela exposição à violência, precárias condições de vida (como a falta de saneamento básico), baixo acesso a alimentos e a pouca assistência nos serviços de saúde (BELLO; BONILLA, 2010, p. 64).

Com efeito, a ausência estatal se traduz na falta de assistência aos serviços essenciais ao desenvolvimento humano, agravado ainda mais pela falta de acesso e conhecimento das PDIs em relação aos seus direitos, conforme aponta o estudo de Bello e Bonilla (2010, p. 78), quando chamam atenção para o fato de que "quase $60 \%$ dos deslocados declararam não conhecer seus direitos em matéria de atenção à saúde e mais de $40 \%$ desconheciam os requisitos para usar os serviços médicos e os horários de atendimento".

O desconhecimento em relação aos seus direitos não se materializa apenas na área da saúde, corresponde aos diversos domínios sociais, ocasionados especialmente pela negligência governamental e pelo estado de intensa vulnerabilidade aos quais são submetidos. As demonstrações quantitativas explanadas neste capítulo elucidam o transbordamento da crise gerada pelo processo de deslocamento interno, sentida pela população em geral, tanto pelos deslocados como os receptores. As consequências deste fenômeno, quando aliadas a um Estado omisso e às ações oriundas do conflito armado, provocam inúmeras violações de direitos humanos, a grande maioria negligenciada pelo governo, seguida pela ameaça e pelo assassinatos de pessoas envolvidas em processos criminais relacionados aos diretos humanos, tais como advogados, testemunhas e líderes de Organizações Não Governamentais.

\section{O Estado Colombiano e sua relação com as PDIs}

A resposta do Estado veio, mas num momento tardio e de forma gradativa. Isso porque, mesmo que a violência gerada pelo conflito armado já tivesse impulsionado o fenômeno do deslocamento interno desde a década de 1980, o Estado colombiano só começou a formular um corpo normativo voltado ao tratamento desta crise a partir dos anos de 1990 (VIANA, 2009, p. 144). Sem dúvida, as primeiras iniciativas do governo corresponderam à conjunção dos fatores internos, pelos graves efeitos do deslocamento, mas também ao movimento internacional que sentiu a necessidade de propor soluções e prevenir o êxodo interno forçado, que chamara atenção pelo seu progressivo crescimento. 
A primeira ação do Estado ocorreu por meio da promulgação da Lei n. 387 de 18 de julho de 1997 - pela qual se adotaram "medidas para la prevención del desplazamiento forzado; la atención, protección, consolidación y estabilización socioeconómica de los desplazados internos por la violencia en la República de Colombia"7 (COLÔMBIA, 1997a) - antes mesmo da apresentação dos PORDI (ONU, 1998) à Comissão de Direitos Humanos da ONU. Isso quer dizer que os Princípios Orientadores não tiveram uma influência direta na elaboração desta norma, fato possivel de ser observado ao olharmos a conceitualização empregada ao termo "deslocado" na redação dos dois textos.

Enquanto que os PORDI trazem uma abordagem um pouco mais ampla para categorizar os deslocados internos como pessoas que são forçadas a saírem de suas casas envolvendo situações que vão desde conflitos internos até calamidades humanas ou naturais, no texto da Lei 387/978 há um enfoque mais restritivo, identificando os deslocados como pessoas que foram obrigadas a migrar dentro do território nacional em virtude dos casos de violência interna, conforme observamos na definição abaixo.

Apesar da diferença no emprego do termo deslocado, a focalização das necessidades das PDIs através desta lei seguiu as orientações previstas anteriormente pelo Representante Especial do Secretário-Geral para Deslocados Internos, facilitando, dessa forma, um maior alinhamento aos Princípios Orientadores. Mesmo assim, Mojica (2007, p. 162) assinala que a definição, que surge desta exegese, enquadra-se mais nas ações do Estado em resposta ao conflito interno do que na simples descrição da problemática, ou seja, refere-se a uma construção elaborada com vias a incorporar a atenção aos deslocados no marco das estratégias de enfrentamento do conflito armado, por isso é interpretada de forma restritiva.

De outro lado, não podemos negar que a Lei n. 387/97, enquanto instrumento normativo, tornou-se um marco para o tratamento do deslocamento interno na Colômbia. Sua relevância reside no fato de ter sido responsável pelo, em primeiro lugar, reconhecimento de que as PDIs deveriam receber atenção especial e que por isso necessitavam de garantias frente às dificuldades enfrentadas antes, durante e depois do deslocamento; em segundo, por reconhecer a responsabilidade do Estado na formulação de políticas e na adoção de medidas para prevenção, atenção, proteção, consolidação e estabilização socioeconômica da população deslocada em situação de violência; e, por fim, pela aceitação correlata de que os deslocados possuem direito de receber auxílio da comunidade internacional.

Dentre as provisões contidas na Lei n. 387/97 (COLOMBIA, 1997a), destacamos a criação de alguns mecanismos que fornecem o suporte para elaboração de políticas públicas voltadas à proteção das PDIs, como o Sistema Nacional de Atenção Integral à População Deslocada por

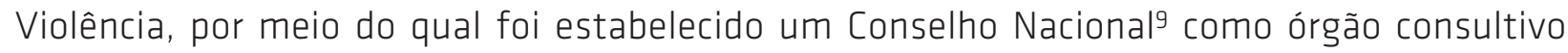

7 Elaborada e aprovada durante o governo de Ernesto Samper Pizano (1994-1998).

8 É deslocada toda pessoa que se tenha visto forçada a migrar dentro do território nacional, abandonando sua localidade de residência ou atividades econômicas habituais porque sua vida, sua integridade física, sua segurança ou liberdade pessoais tenham sido vulneradas ou se encontram diretamente ameaçadas por ocasião de qualquer das seguintes situações: conflito armado interno, distúrbios e tensões internas, violência generalizada, violações maciças de Direitos Humanos, infrações ao Direito Internacional Humanitário ou outras circunstâncias emanadas das situações anteriores que possam alterar ou aterem drasticamente a ordem pública (COLÔMBIA, 1997a, art. 1º, tradução livre).

9 Composto por membros do governo, representantes da Cruz Vermelha Colombiana, da Defesa Civil, das Igrejas, da População Deslocada, entre outros. 
e assessor; o Plano Nacional de Atenção Integral da População Deslocada por Violência, que criou uma Rede Nacional de Informação; e o Fundo Nacional de Atenção Integral da População Deslocada por Violência.

O Sistema Nacional de Atenção Integral à População Deslocada por Violência (SNAIPD) pretende atender às PDIs de maneira que possa mitigar e até neutralizar as dinâmicas da violência que ocasionam o processo de deslocamento, além de integrar esforços, junto aos setores públicos e privados, para promover uma política adequada de prevenção e atenção aos deslocados, assim como direcionar recursos humanos, técnicos, administrativos e econômicos para o mesmo fim, o que significa dizer que o objetivo central do SNAIPDV10 é estabelecer redes de apoio às pessoas que estejam tanto na eminência de deslocarem-se, como as que já estão em situação de deslocamento e executar as políticas de atenção à população deslocada (COLÔMBIA, 1997a).

O Plano Nacional de Atenção Integral da População Deslocada por Violência foi pensado com o propósito de criar e adotar medidas que garantam uma atenção especial às PDIs, a começar pela criação da Rede Nacional de Informação, que possibilitaria o registro e diagnóstico das causas e agentes que ocasionam o deslocamento no Estado e forneceria uma base de dados, a fim de demonstrar as dimensões do fenômeno. Por meio deste Plano, também foi elaborado um mecanismo de Atenção Humanitária de Emergência, fundamental na assistência às pessoas em situação de deslocamento, responsável por promover ações imediatas com a finalidade de:

"socorrer, asistir y proteger a la población desplazada y atender sus necesidades de alimentación, aseo personal, manejo de abastecimientos, utensilios de cocina, atención médica y psicológica, transporte de emergencia y alojamiento transitorio en condiciones dignas"11 (COLÔMBIA, 1997a).

Neste interim, convém destacar a vigência do Decreto n. 2569 (COLOMBIA, 2000), que regulamentou a Lei n. 387/97 e trouxe importantes disposições acerca da condição do deslocado e das redes de apoio às PDIs, como a determinação de que a Red de Solidaridad (RSS)12 passasse a coordenar o SNAIPD, de modo que pudesse promover uma melhor integração dos programas entre as instituições públicas em todos os nivveis de ação - nacional, estadual e municipal - para atenção às PDIs (COLÔMBIA, 2000, art. $1^{\circ}$ ).

Da mesma forma, criou o Sistema Único de Registro da População Deslocada (SUR)13, direcionado à quantificação da população afetada pelo deslocamento, com o intuito de manter um cadastro atualizado, em termos territoriais e populacionais, das pessoas que necessitam das políticas estatais direcionadas aos deslocados.

10 Regulamentado parcialmente pelo Decreto n. 2007 de 2001 (COLOMBIA, 2001), referente ao artigo $7^{\circ}$, acerca da atenção à população rural deslocada por violência.

11 Trad.: "Socorrer, assistir e proteger a população deslocada e atender suas necessidades de alimentação, higiene pessoal, suprimentos, utensílios de cozinha, atenção médica e psicológica, transporte de emergência e alojamento transitório em condições dignas" (tradução nossa).

12 Entidade do governo vinculada diretamente à Presidência da República.

13 Para o registro no SUR é exigido ao requerente uma declaração que alegue sua condição de deslocado, na qual devem constar os seguintes itens: 1. fatos e circunstâncias que o obrigaram a fugir; 2. lugar de origem; 3. profissão e ocupação; 3. atividade econômica que exercia e mercadorias e bens que possuía antes do deslocamento; 4. razões para a escolha do lugar de chegada. A referida declaração deverá ser apresentada dentro do ano seguinte à ocorrência do deslocamento. Após a apresentação da declaração na entidade delegada para o recebimento, o requerente precisará esperar 15 dias úteis para obter a resposta de sua solicitação. 
O Decreto n. 2569 (COLÔMBIA, 2000) também elenca uma série de critérios determinantes para a cessação da condição do deslocamento. Segundo seu art. $3^{\circ}$, o Estado colombiano entende que um indivíduo passa a ser considerado não deslocado quando apresenta as seguintes situações: seu retorno ao lugar de origem, o reassentamento ou relocação em outro lugar seguido ao acesso a uma atividade econômica, exclusão do SUR, em conformidade com as disposições previstas no artigo 14 do referido Decreto, ou por solicitação do interessado.

Mais recentemente, tendo em vista as consequências do conflito armado para a população em geral, em particular aos deslocados internos, do qual decorre sobremedida violações ao direito à liberdade de locomoção e residência, e ao direito à proteção frente a toda ingerência domiciliar ou à vida privada, cometida quando da expropriação forçada da terra ou das casas, foi igualmente promulgada pela Colômbia a Lei n. 1448/11 "por la cual se dictan medidas de atención, asistencia y reparación integral a las víctimas del conflicto armado interno y se dictan otras disposiciones"14. Esta lei destina aos deslocados internos, por meio de um enfoque diferenciado, três fases ou etapas para as medidas de assistência e atenção - de forma a complementar a política de prevenção e estabilização socioeconômica estabelecida na Lei n. 387/97 - , a saber: atenção imediata, atenção humanitária de emergência e atenção humanitária de transição (COLÔMBIA, 2011b).

A atenção imediata se presta às vitimas do deslocamento interno que apresentam elevado grau de vulnerabilidade e que necessitam de alojamentos temporários e assistência alimentar, reconhecidos ante o Ministério Público, por meio do cadastro no SUR ${ }^{15}$. A atenção humanitária de emergência ocorre através da Agência Presidencial para la Acción Social, a quem já detenha seu registro no SUR, da qual resultará as assistências essenciais à subsistência mínima do deslocado na localidade de chegada (COLÔMBIA, 2011b, arts. 63-65, respectivamente).

O plano desta lei representa um avanço importante com relação à proteção dos direitos humanos dos deslocados internos, porque consagra a obrigação do Estado em desenhar medidas especiais referentes ao retorno, reintegração e restituição aos locais de origem dos deslocados. Para fornecer meios visando à restituição da terra, a referida lei criou um "Registro de terras despojadas e abandonadas forçosamente", a fim de identificar com precisão o valor do objeto de despojo, mediante a posição geográfica e verificando o período em que foi investida influência armada à propriedade (COLÔMBIA, 2011b, art. 76).

No entanto, toda esta normatividade, ainda que em conformidade com os princípios do Direito Internacional Humanitário e Direito Internacional dos Direitos Humanos, não consegue abarcar em sua completude os dilemas enfrentados pelos deslocados colombianos. Na avaliação de Mojica (2007, p. 159), o governo cumpriu formalmente a indicação da comunidade internacional de formular um plano nacional de ação direcionado para as PDIs, mas o arcabouço jurídico colombiano, nesta área, ainda possui algumas brechas, além de muitas falhas em seu processo de implementação.

14 Trad.: "Pela qual se ditam as medidas de atenção, assistência e reparação integral às vítimas do conflito armado interno e se ditam outras disposições" (tradução nossa).

15 Poderão receber este tipo de ajuda os deslocados, quando do momento da chegada ao município de recepção, dentro do período

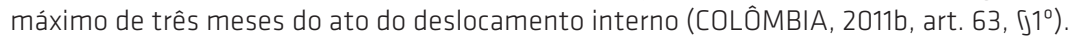


A começar pela subjetiva distinção entre deslocado e população, objeto da atenção estatal, presente na Lei n. 387/97, uma vez que tende a identificar os deslocados como uma das partes envolvidas no conflito, e não como a parte da população civil. Isso ocorre porque a dinâmica do Sistema Nacional de Atenção Integral à População Deslocada por Violência incorpora os indivíduos na condição de PDIs como beneficiários de programas públicos, e não como sujeitos titulares de direitos fundamentais. O que significa dizer que sua inclusão e participação ao SNAIPD podem sofrer limitações, tendo em vista que para execução dos programas governamentais torna-se necessário a disponibilidade e canalização de recursos, e estes nem sempre são suficientes para atender as demandas dos deslocados, que aumentam ano após ano, ou não são prioritariamente direcionados para este fim (MOJICA, 2007, p. 158).

Esta problemática decorre, em primeiro lugar, pelas falhas no Sistema de Registro Único da População Deslocada, peça-chave do SNAIPD, dado que é a partir desta ferramenta que são identificadas as pessoas afetadas pelo deslocamento e traçados os serviços essenciais à sua proteção, ou seja, não se trata apenas de um registro para mensuração do fenômeno, mas especialmente de um pré-requisito para obtenção da Ajuda Humanitária de Emergência16 e dos demais benefícios consagrados na Lei n. 387/97. Diferentes organizações já demonstraram, como a organização não governamental Refugees International, que o governo colombiano vem sistematicamente subestimando o número de PDIs, por meio do SUR, e assim negando milhares de serviços aos deslocados em vulnerabilidade (DARIO, 2009, p. 12).

Uma das dificuldades reside no momento mesmo do indivíduo expulso obter o certificado de deslocado interno. O lapso temporal e as documentações exigidas retardam e acabam até mesmo ocasionando a não inscrição no SUR. A Refugees International (2007, p. 02) identificou entre as PDIs, pelo menos, quatro entraves à inscrição no Sistema: primeiro, pessoas deslocadas em virtude da repressão política ou de operações militares não podem registrar-se, já que estas ações não envolvem outros atores armados e por isso não são definidas como conflito; segundo, os civis deslocados como consequência da prática da fumigação no combate ao cultivo da coca também não são considerados; terceiro, as famílias que não conseguem declarar satisfatoriamente as circunstâncias que as obrigaram a fugir - muitas vezes pelo trauma sofrido ou por não identificarem os autores temendo represálias - acabam tendo suas solicitações negadas por serem consideradas incompletas; por fim, o governo continua a rejeitar as pessoas que não se registram dentro de um ano da sua deslocação, mesmo que as disposições legais (Decreto n. 2569/2000) permitam aos deslocados se inscreverem após o primeiro ano. 0 mais agravante dessas falhas é que, não conseguindo o cadastro no SUR, as pessoas em situação de deslocamento acabam não acessando os programas públicos específicos aos deslocados.

Segue, assim, uma constante assimetria entre o corpo normativo e o desempenho institucional de atenção à população deslocada. O Estado ainda demonstra despreparo para atender ao elevado contingente de PDIs e as agências do governo transbordam sua capacidade de funcionamento, o que significa dizer que as administrações municipais e estaduais se afrontam constantemente com as tensões entre as PDIs e as populações receptoras (REFUGEES INTERNATIONAL, 2008, p. 01). Inclusive, a Lei n. 387/97 reflete debilmente os impactos que os

16 De acordo com a Lei n. 387/97 (COLOMBIA, 1997a, art.15, Jjúnico), os deslocados internos possuem o direito à Ajuda Humanitária de Emergência por um período de três meses, prorrogável excepcionalmente por mais três. 
deslocamentos causam aos habitantes das zonas de recepção, que, da mesma forma que os deslocados, não conseguem satisfazer plenamente suas necessidades básicas. A superficialidade com que a norma aborda essa questão, quando assinala em seu art. $9^{\circ}$ que o Plano Nacional deverá adotar medidas e ações que atendam as características e condições especiais das "zonas de expulsão" e das "zonas de recepção", acaba materializando-se pela ausência de políticas que promovam uma melhor assimilação das PDIs nos locais de chegada (MOJICA, 2007, p. 159).

Para o ACNUR (ONU, 2004b, p. 72), uma debilidade de tipo estrutural que continua vigente, além da falta de monitoramento e avaliação, corresponde à descoordenação da política em termos intersetoriais, em particular no que diz respeito à estabilização socioeconômica das PDIs. As iniciativas governamentais nesta área têm sido deficitárias, em parte, por não criarem condições de vida que estimulem os deslocados a permanecerem nos locais de recepção, devido ao acesso desigual à saúde, educação, moradia e emprego, mas também porque os programas de reassentamento são conduzidos em áreas sem infraestrutura adequada e inseguras, obrigando algumas famílias a se deslocarem mais de uma vez (MOJICA, 2007, p. 160).

Afora isso, a Anistia Internacional (2013, p. 63) assinalou, no último informe acerca da Colômbia, que a Lei de Vítimas e Restituição de Terras, em vigor desde $1^{\circ}$ de janeiro de 2012 , provocou a reação contrária de quem se beneficiou das expropriações, uma vez que as pessoas que se mobilizaram pela restituição, bem como as que tentaram voltar para suas terras, foram assassinadas ou ameaçadas.

Esse quadro de constante debilidade na proteção das PDIs, e de dissonância com os ordenamentos jurídicos internos, também foi comprovado pela Corte Constitucional da Colômbia, por meio da sentença T-025/04, quando manifestou as inconsistências na política de atenção integral à população deslocada, declarando formalmente que tal situação figurava-se como um "estado inconstitucional das coisas" (COLOMBIA, 2004). Nesta ocasião, a Corte verificou a sistemática violação dos direitos fundamentais da população deslocada, assim como a existência de diversas falhas entre as instituições responsáveis pela proteção de suas garantias.

Em resumo, a sentença T-025 de 2004 compreendeu a conjunção de petições movidas por 1.150 famílias deslocadas, integradas principalmente por mulheres, idosos, crianças e alguns indígenas em diversas localidades. Entre elas, foram identificados problemas comuns, resultantes, na maior parte dos casos, da Ajuda Humanitária de Emergência prestada pelo Estado colombiano, durante os três meses seguintes após a sua chegada (COLÔMBIA, 2004).

A Corte fundamentou seu parecer levando em consideração os problemas jurídicos relacionados ao SNAIPD decorrente, no primeiro momento, da grave situação de vulnerabilidade das PDIs e dos problemas na prestação de serviços pelas entidades demandadas, em razão dos atrasos e da omissão à proteção efetiva dos deslocados pelas autoridades competentes, e depois, pela constatação dos problemas estruturais que afetam o Plano Nacional, em seus distintos componentes, com relação à insuficiência dos recursos destinados ao referido plano e à precária capacidade institucional para empregá-lo (COLOMBIA, 2004).

Dois pontos devem ser destacados em relação a esta sentença: o primeiro reside no fato da Corte ter considerado os PORDI (ONU, 1998) como jurisprudência para ressaltar os direitos fundamentais dos deslocados internos, e o segundo, particularmente importante, é que esta decisão tornou-se um precedente para observância de outros casos, em que as especificidades 
da T-025/04 foram suscitadas para emissão de novos pareceres, como o que resultou na Sentença T-349/1217 acerca da obrigação do Estado em garantir o direito à moradia digna à população deslocada, na qual se expôs que - frente às dificuldades das PDIs em encontrar condições apropriadas de alojamento, posto que muitas chegam aos lugares totalmente desprovidas - o Estado deve prover meios que possibilitem aos deslocados auferirem habitações adequadas e que estas não podem ser despojadas dos lugares de ocupação, mesmo que irregulares, sem que haja um planejamento de reassentamento em outras localidades.

Por fim, com base nas informações elencadas neste tópico, constatamos os avanços e retrocessos no enfrentamento do deslocamento interno pelo Estado colombiano. A promulgação das Leis 387/97 e 1448/11 e as sentenças deliberadas pela Corte Constitucional da Colômbia, sem dúvida, constituem-se como os maiores avanços em matéria de proteção aos direitos humanos das PDIs, especialmente porque através destas normas foi estabelecido um alinhamento aos PORDI, o que permitiu sua maior difusão entre as entidades do governo nacional. Contudo, tanto a difusão dos PORDI como o ordenamento jurídico interno não foram suficientes para materialização das garantias dos deslocados.

As falhas estruturais do SNAIPD colocaram novos desafios às pessoas deslocadas, que passaram a conviver com uma política nacional engessada e descoordenada, fruto de programas governamentais que respondem esporadicamente às suas demandas, com recursos limitados e que, em geral, está sujeita à vontade política dos representantes locais.

\section{Avaliação da atuação do Estado colombiano no contexto do deslocamento interno na Colômbia segundo os PORDI}

A partir dos pontos focais desta pesquisa, sublinhamos que os deslocamentos internos na Colômbia seguem, em sua maioria, como consequência direta do conflito armado e da cultura política da violência enraizada no território colombiano, motivações que colocaram o Estado entre os que mais apresentam vítimas deste fenômeno. Sabendo disso, assinalamos o fosso existente na proteção nacional das PDIs pelo governo da Colômbia que, paradoxalmente, é um dos agentes do deslocamento e um defensor dos direitos humanos dos deslocados.

Demonstramos, ao longo do texto, que, mesmo tardiamente, a resposta internacional produziu efeitos positivos para o tratamento do deslocamento interno, como a redação dos PORDI, que foram internalizados pela Colômbia, possibilitando a produção de normas, como a promulgação da Lei n. 1448/11, e sua aplicação por meio da Corte Constitucional, na emissão dos pareceres acerca das violações aos direitos das PDIs. Da mesma forma, no âmbito externo, os PORDI tornaram-se uma importante ferramenta para elaboração dos planos de ação das instituições internacionais, que através deles passaram a atuar em razão das vulnerabilidades específicas enfrentadas pelos deslocados, envolvendo assim desde a proteção contra o deslocamento até o seu término.

Mesmo pautadas nos PORDI, as estratégias adotadas pelo Estado são limitadas. A questão agrária, um dos principais condicionantes do conflito, permanece carente de uma reforma e por isso continua longe de ser resolvida, devido ao vínculo estabelecido com os grupos de

17 Caso: Epaminondas Córdoba Bravo contra la Gobernación de Casanare y otros. 
narcotraficantes, para o uso ilícito da terra na produção das drogas, o que acaba dificultando a implementação de programas que visem a estabilização da população nestas zonas.

Além disso, precisamos tomar nota de que a Colômbia, mesmo que imersa num conflito interno, é vista como um Estado relativamente forte, o que, por possuir um sistema político consolidado e mecanismos nacionais para atender os deslocados, aumenta as chances das PDIs verem seus direitos garantidos. Contudo, nem sempre a existência da normatividade e de políticas públicas são sinônimos de efetividade, fato comprovado pelas falhas demonstradas no SNAIPD.

Nesse sentido, o Estado colombiano desrespeita, por não adotar medidas que evitem as populações de se deslocarem, os princípios de 5 a 9 dos PORDI (ONU, 1998), especialmente no que tange ao direito à liberdade de locomoção e residência, ao direito à proteção frente a toda ingerência domiciliar ou à vida privada, e à proibição das deslocações forçadas, isso porque poucas foram as iniciativas para estabelecer um acordo de paz com os insurgentes, na verdade, a principal aproximação entre o governo e os insurgentes só pôde ser observada mais recentemente, em 2012, a partir da intermediação do Estado cubano nas negociações. Trata-se de um passo significativo para alcançar um acordo de paz, mas que ainda demanda maiores esforços, tendo em vista os diversos problemas estruturais que aprofundaram o conflito na região - como a reforma agrária, participação política dos rebeldes e drogas ilícitas -, tratados até o momento de forma parcial.

Ademais, em virtude do conflito interno, o Estado age, através das forças nacionais, estimulando o deslocamento, apoiando formas de coação violentas, destinadas a produzir a desapropriação das terras, justificando-se com o falso discurso de que ações, como as fumigações, são necessárias ao combate às plantações de produtos ilícitos, dos quais provém o principal financiamento dos grupos armados.

Demonstramos também que a parcela da população mais atingida pelo deslocamento na Colômbia é de camponeses e indígenas e afro-colombianos, grupos de pessoas que possuem dependência e/ou ligação especial com suas terras, o que acaba realçando que a primeira esfera destacada pelos PORDI para promover a proteção dos indivíduos contra o deslocamento não é atingida pelas políticas nacionais, não encontrando soluções duráveis para o problema, ocasionando a violação do princípio 9 dos PORDI.

Tratando-se do próprio processo de deslocação, os desrespeitos são ainda maiores e afetam todos os meios para o desenvolvimento dos deslocados nas localidades de chegada, envolvendo, principalmente, áreas como a saúde, educação, segurança e emprego. Neste contexto, a omissão estatal, as falhas relacionadas ao SNAIPD e a falta de comprometimento com as PDIs são os fatores preponderantes para as lacunas na sua proteção.

Um exemplo dessa conjuntura são as dificuldades que os deslocados enfrentam para obter a documentação adequada, a fim de ascender aos programas de assistência do governo, o que acaba elucidando o descumprimento dos PORDI (ONU, 1998, princípio 27), quando assinala o dever do Estado de prover condições de vida satisfatórias e assistência humanitária à população deslocada.

Segue-se que a principal lacuna, em matéria de proteção aos deslocados internos, reside na esfera das garantias após o final do deslocamento. As tentativas para estabelecer o 
retorno seguro, ou a reintegração, e o ressarcimento dos bens perdidos são insuficientes e mal planejadas, e têm ocasionado efeito reverso para as famílias que buscam tal direito. Além disso, as políticas de reassentamento demonstram o descaso com o qual são consideradas as PDIs, que são alocadas em locais sem infraestrutura e com dificuldade de acesso, descumprindo assim os princípios 28-30 dos PORDI (ONU, 1998).

O fato é que a resposta do Estado às necessidades das PDIs continua sendo seletiva e negligente. Seletiva porque, como os recursos são escassos e as capacidades limitadas, as instituições escolhem as situações com as quais irão atuar, dependendo de suas prioridades, interesses políticos, do capital financeiro, tornando-se assim atuações descoordenadas e inconsistentes. E negligentes, porque apresentam falhas nos planos de ação voltados a suprir as necessidades dos deslocados, particularmente no que se refere às medidas de longo prazo, como educação e desenvolvimento socioeconômico, à prevenção e ao retorno/reintegração dos deslocados ao local de origem (TIM0, 2009, p. 16).

Diante das proposições elencadas neste estudo, verificamos que há um longo caminho a percorrer em matéria de proteção aos direitos humanos dos deslocados internos, uma vez que as lacunas na proteção das PDIs existem não pela ausência de normas, mas pela falta de vontade e interesse dos governantes em pô-las em prática; pelos intervenientes inerentes ao conflito interno e à complexa rede de atores envolvidos nas formas de violência perpetradas contra a população civil; por problemas estruturais, como a questão agrária; e pela falta de comprometimento da comunidade internacional, que tardou a buscar respostas para esta problemática, bem como pelo Estado colombiano.

Em resumo, os desrespeitos constatados nestas três esferas elencadas pelos PORDI contrariam o ordenamento vigente nesta matéria, uma vez que tanto a normatividade nacional como internacional possuem brechas, colaborando para que as demandas das PDIs não sejam atendidas plenamente. Ademais, reforçamos que a internalização das normas internacionais não é suficiente para proteção dos deslocados internos, se em contrapartida não houver interesse e investimentos do Estado para sua materialização, o que de fato não acontece na Colômbia.

\section{Conclusão}

A concepção deste estudo ocorreu em meio às violações dos Direitos Humanos na Colômbia, mais precisamente, aos casos de violações contra os deslocados internos. Partindose dessa conjuntura, o presente artigo pretendeu analisar a proteção internacional dos direitos humanos, no campo de aplicação dos PORDI, tendo como base um estudo de caso sobre a sua efetividade em relação aos deslocados internos na Colômbia.

Em se tratando dos Princípios Orientadores relativos aos Deslocados Internos, constatamos alguns avanços, mas também uma série de desafios. Com relação aos avanços, assinalamos as três esferas delimitadas para fornecer atenção aos deslocados, - que abarcam desde a prevenção do desenraizamento ilegal, a proteção durante o deslocamento até o seu regresso ou reinstalação e reintegração ao local de origem - e por ter sublinhado diretrizes que não são abarcadas no escopo dos direitos humanos e humanitário, como os princípios relativos 
aos reassentamento e reintegração das PDIs ao local de origem, elucidando este princípio como um dos elementos indispensáveis para reintegração dos deslocados à sociedade e para plena salvaguarda dos seus direitos.

De outro lado, mesmo que elucidado, a questão da assistência humanitária foi pouco desenvolvida pelos PORDI. Pela sua especial importância, tendo em vista que muitos Estados não estão preparados ou são omissos em relação à proteção das PDIs e acabam necessitando do apoio internacional, os princípios relativos à prestação de assistência aos deslocados internos mereciam uma melhor apreciação neste documento.

Nesse contexto, endossamos que a falta de vontade política se fortalece a partir do momento em que o Estado não encontra uma força normativa específica que o coaja a agir de maneira a proteger os PDIs, a fim de evitar possíveis sanções externas, o que acaba se tornando o principal desafio dos PORDI.

Destacamos, no primeiro momento, que os PORDI impactaram de forma positiva o ambiente interno da Colômbia, uma vez que foram produzidos avanços no ordenamento direcionados à proteção dos deslocados internos. A promulgação das Leis 387/97 e 1448/11 e as sentenças deliberadas pela Corte Constitucional da Colômbia permitiram uma maior difusão dos PORDI.

Contudo, tanto a difusão dos PORDI como o ordenamento jurídico interno não foram suficientes para materialização das garantias dos deslocados. As falhas estruturais do SNAIPD colocaram novos desafios às pessoas deslocadas, que passaram a conviver com uma política nacional engessada e descoordenada, fruto de programas governamentais que respondem esporadicamente às suas demandas, com recursos limitados e que, em geral, estão sujeitos à vontade política dos representantes locais. Com isso, é perceptível a fragilidade na relação entre o Estado colombiano e as PDIs, conforme demonstramos nas lacunas e problemáticas na execução da política nacional de atenção às pessoas em situação de deslocamento explanadas neste estudo.

\section{Referências}

ANISTIA INTERNACIONAL. 2013. Informe 2013: o estado dos direitos humanos no mundo. 180p. Disponível em: [http://files.amnesty.org/air13/AmnestyInternational_AnnualReport2013_complete_br-pt.pdf]. Acesso em: 15 mar. 2014.

BELLO, Amparo Hernández; BONILLA, Martha Lucía Gutiérrez. Vulnerabilidad y exclusión em salud: datos y relatos de la situación de la población desplazada en Bogotá. Bogotá: Pontificia Universidad Javeriana, 2010, 288p.

CENTRO NACIONAL DE MEMORIA HISTÓRICA. jBasta ya!: Colombia - memorias de guerra y dignidad. Bogotá: Imprenta Nacional, 2013, 434p.

COLOMBIA. 1997. Congreso de la República de Colombia. Lei n. 387, de 18 de julho de 1997: por la cual se adoptan medidas para la prevención del desplazamiento forzado; la atención, protección, consolidación y estabilización socioeconómica de los desplazados internos por la violencia en la República de Colombia. Disponivel em: [http://www.unhcr.org/refworld/docid/3dbd4c6b5.html]. Acesso em: 25 fev. 2014. 
2011b. Congreso de la República de Colombia. Lei n. 1448, de 10 de junho de 2011: por la cual se dictan medidas de atención, assistência e reparación integral a las víctimas del conflito armado interno y se dictan outras disposiciones (Ley de victimas y restitucion de tierras). Disponível em: [http://www. archivogeneral.gov.co/?idcategoria=4419]. Acesso em: 01 mar. 2014.

.1995. Conselho Nacional de Política Econômica e Social - CONPES. CONPES 2804: Programa Nacional de Atención Integral a la Población Desplazada por la Violencia.

(Documento n. 2804, de 13 de setembro de 1995). Disponível em: [http://www.refworld.org/ docid/46d57e112.html]. Acesso em: 25 fev. 2014.

1997. Conselho Nacional de Política Econômica e Social - CONPES. CONPES 2924: Sistema Nacional de Atención Integral a la Población Desplazada por la Violencia (Documento n. 2924, de 28 de maio de 1997). Disponível em: [http://www.refworld.org/docid/46d57efa2.html]. Acesso em: 25 fev. 2014.

2004. Corte Constitucional de Colombia. Sentença T-025 de 2004. Disponivel em: [http://www. corteconstitucional.gov.co/relatoria/2004/t-025-04.htm]. Acesso em: 25 fev. 2014.

2012. Corte Constitucional de Colombia. Sentença T-349 de 2012. Disponivel em: [http://www. corteconstitucional.gov.co/relatoria/2012/t-349-12.htm]. Acesso em: 25 fev. 2014.

2011. Defensoría del Pueblo de Colombia. Coordinación de Atención al Desplazamiento Forzado. Persistencia del desplazamiento forzado interno em Colômbia: dinámica del desplazamiento forzado. Colômbia: Defensoría del Pueblo, 25p. Disponivel em: [http://www.defensoria.org.co/red/index.php?_ item=110507\&_secc=11\&ts=2\&hs=1105]. Acesso em: 24 jan. 2014.

2001. Secretaría Ceneral de la Alcadía Mayor de Bogotá. Decreto n. 2007, de 24 de setembro de 2001. Disponivel em: [http://www.brookings.edu/ /media/Projects/idp/Colombia_Decreto2007_2001.PDF]. Acesso em: 25 fev. 2014.

2000. Secretaría General de la Alcadía Mayor de Bogotá. Decreto n. 2569, de 12 de dezembro de 2000. Disponivel em: [http://www.alcaldiabogota.gov.co/sisjur/normas/Norma1.jsp?i=5365]. Acesso em: 25 fev. 2014.

COHEN, Roberta. 1998. The Guiding Principles on Internal Displacement: a new instrument for international organizations and NGOs. Forced Migration Review, p. 31-33, Aug. 1998.

COHEN, Roberta; DENG, Francis Manding. 2008. Orígenes y desafios. Revista Migraciones Forzadas: Alicante [Universidad de Alicante], ed. esp. [Diez años de los principios rectores del desplazamiento interno] p. 04-05.

CUNHA, Guilherme da. 2002. Migrantes e refugiados: marco jurídico e estratégia no limiar do século XXI. In: PINHEIRO, Paulo Sérgio; GUIMARÃES, Samuel Pinheiro (orgs). Direitos humanos no século XXI. Brasília, DF: IPRI/ FUNAG, 2002, p. 495-518.

DARIO, Diogo Monteiro. 2009. As Populações Internamente Deslocadas pelo conflito colombiano durante o governo Uribe: uma reflexão sobre os usos da segurança humana na era da "Guerra contra o Terror". $157 f$. Dissertação (Mestrado em Relações Internacionais)- Pontifícia Universidade Católica do Rio de Janeiro, Rio de Janeiro. Disponível em: [http://www.maxwell.lambda.ele.puc-rio.br/14094/14094_1.PDF]. Acesso em: 23 jun. 2013. 
EVANS, Gareth. 2008. The Responsibility to Protect: ending mass atrocity crimes once and for all. Washington: The Brookings Institution, 348p.

GLOBAL DATABASE. 2013. Guiding Principles on Internal Displacement: The guiding principles: Introduction to the guiding principles. Disponivel em: [http://www.idpguidingprinciples.org/]. Acesso em: 24 maio 2013.

GRACE, Jeremy; FISCHER, Jeff. 2008. Garantizar la igualdad electoral a los votantes desplazados. Revista Migraciones Forzadas, Alicante [Universidad de Alicante], ed. esp. [Diez años de los principios rectores del desplazamiento interno], p. 26-27.

INTERNAL DISPLACEMENT MONITORING CENTRE - IDMC. Clobal IDP estimates (1990-2011). 2011 . Disponivel em: <http://www.internal-displacement.org/8025708F004CE90B/(httpPages)/10C43F54 DA2C34A7C12573A1004EF9FF?OpenDocument>. Acesso em: 13 nov. 2013.

Colombia: property restitution in sight but integration still distant. Geneva: Norwegian Refugee Council, 2011b, 79p.

2013. Global Overview 2012: People internally displaced by conflict and violence. Geneva: Norwegian Refugee Council, 74p.

KÄLIN, Walter; KÜNZLI, Jörg. 2009. The law of international human rights protection. Oxford: Oxford University Press, 539p.

MARTIN, Susan Forbes. 1999. Manual de aplicação dos principios orientadores relativos aos deslocados internos [Projecto sobre Deslocação Interna]. Nova Iorque: Gabinete das Nações Unidas para a Coordenação dos Assuntos Humanitários - OCHA, 77p.

MOJICA, Beatriz Eugenia Sánchez. 2007. El Estatuto Constitucional del Desplazado Interno en Colombia. 515f. Tese (Doutorado em Direitos Fundamentais)- Universidad Carlos III de Madrid, Madrid. Disponivel em: [http://e-archivo.uc3m.es/handle/10016/5216?show=full]. Acesso em: 25 fev. 2014.

MURCIA, Luis Eduardo Pérez. Desplazamiento forzado en Colombia 1995-1999: una aproximación empírica a las relaciones entre desplazamiento, conflicto armado y desarrollo. In: SUÁREZ, Hernán (ed.). El Desplazamiento forzado en Colombia: compromisos desde la universidad [primer concurso universitária de trabajos de grado sobre desplazamiento forzado en Colombia]. Bogotá: Asociación Colombiana de Universidades - ASCUN e CODHES, 2002, p. 17-88.

NASCIMENTO, Allan. 2011. Pessoas deslocadas internamente: da atuação do estado soberano à intervenção da comunidade internacional. Sociologia, problemas e práticas, n. 66, p. 117-134.

OLIVEIRA, Eduardo Cançado. 2004. A proteção jurídica internacional dos deslocados internos. Revista do Instituto Brasileiro de Direitos Humanos, Fortaleza, v. 5, n. 5, p. 73-92.

ORGANIZAÇÃO DAS NAÇÕES UNIDAS - ONU. 2004b. Alto Comissariado das Nações Unidas para os Refugiados - ACNUR. Balance de la política pública de prevención, protección y atención al desplazamiento interno forzado en Colombia (agosto 2002 - agosto 2004). 273p. Disponivel em: [http://www.acnur.org/ biblioteca/pdf/2983.pdf?view=1]. Acesso em: 10 mar. 2014.

2013b. Alto Comissariado das Nações Unidas para Refugiados - ACNUR. Who we help: internally displaced people: On the run in their own land. Disponivel em: [http://www.unhcr.org/ pages/49c3646c146.html]. Acesso em: 22 maio 2013. 
.1951. Assembleia Geral das Nações Unidas - AGNU: Convenção relativa ao estatuto dos refugiados (Resolução A/RES/429(V), aprovada em 28 de julho de 1951). Disponivel em: [http://www.acnur.org/ t3/fileadmin/scripts/doc.php?file=t3/fileadmin/Documentos/portugues/BDL/Convencao_relativa_ao_ Estatuto_dos_Refugiados]. Acesso em: 23 maio 2013.

2010. Alto Comissariado das Nações Unidas para Refugiados - ACNUR: Grupo de trabalho do Grupo Setorial Global de Proteção. Manual para la protección de los desplazados internos 2010, 547p. Disponivel em: [http://www.refworld.org/cgi-bin/texis/vtx/rwmain/opendocpdf.pdf?reldoc=y\&docid= 515419462]. Acesso em: 22 maio 2013.

1998. Alto Comissariado das Nações Unidas para Refugiados - ACNUR. Princípios Orientadores Relativos aos Deslocados Internos - PORDI. Disponivel em: [http://www.ohchr.org/Documents/Issues/ IDPersons/GPPortuguese.pdf]. Acesso em 22 jun. 2013.

1993a. Conselho Econômico e Social das Nações Unidas - ECOSOC: Commission on Human Rights. Comprehensive study prepared by Mr. Francis M. Deng, Representative of the Secretary-Ceneral on the human rights issues related to internally displaced persons, pursuant to Commission on Human Rights resolution 1992/73. In: Further promotion and encouragement of human rights and fundamental freedoms, including the question of the programme and methods of work of the commission (Documento E/CN.4/1993/35, de 21 de janeiro de 1993). Disponivel em: [http://www.unhchr.ch/Huridocda/Huridoca. nsf/TestFrame/fb36ada4f4e26ce68025672f003ef984]. Acesso em: 23 maio 2013.

PHUONG, Catherine. 2005. The international protection of internally displaced persons. Cambridge: Cambridge University Press, 318p.

REFUGEES INTERNATIONAL. 2007. Colombia: flaws in registering displaced people leads to denial of services. Refugees International: a powerful voice for lifesaving action, Washington D.C., 2p. Disponivel em: [http://www.refintl.org/sites/default/files/col07_register.pdf]. Acesso em: 18 mar. 2014.

SPRINGER, Natalia. Colombia: desplazamiento interno - políticas y problemas. Nova lorque: ACNUR [Sección de información sobre la determinación de la condición de refugiado y la protección (DIPS)], jun. 2006, 62p.

TIMO, Pétalla Brandão. Quando o doméstico é internacional: a problemática do deslocamento interno de pessoas. Revista Cadernos de Relações Internacionais, Rio de Janeiro [Instituto de Relações Internacionais - IRI, da Pontifícia Universidade Católica do Rio de Janeiro - PUC-Rio], v. 2, n. 2, 2009, 20p.

TRINDADE, Antônio Augusto Cançado. 2001. Derecho Internacional de los Derechos Humanos, Derecho Internacional de los Refugiados y Derecho Internacional Humanitario: aproximaciones y convergencias. Derechos humanos: Órgano informativo de la Comisión de Derechos Humanos del Estado de México, Cidade do México, v. 8, n. 9, p. 62-67. Disponivel em: [http://www.juridicas.unam.mx/publica/librev/ rev/derhum/cont/49/pr/pro.pdf]. Acesso em: 22 jun. 2013.

VIANA, Manuela Trindade. 2009. Cooperação internacional e deslocamento interno na Colômbia: desafios à maior crise humanitária da América do Sul. Revista Internacional de Direitos Humanos - SUR, São Paulo, v. 6, n. 10, p. 138-161.

WEISS, Thomas; KORN, David. 2006. Internal displacement: conceptualisations and its consequences. Londres: Routlege; Nova Iorque: Routlege, (Global Institutions Series), 181p.

WILLIAMS, Rhodri C. 2012. El Principio Rector 29 y el derecho a la restitución. Revista Migraciones Forzadas, Alicante [Universidad de Alicante], n. 41 [Prevención del desplazimiento], p. 23-24. 